\begin{tabular}{l|l|l|l|l}
\hline Volume 1 & Issue 2 & August (2020) & DOI: 10.47540/ijsei.v1i2.20 & Page: $53-62$ \\
\hline
\end{tabular}

\title{
Analysis of Development Performance of the New Autonomous Region in Indonesia 2010-2014: Profile and Determinant
}

\author{
Lambang Haris Wijayanto ${ }^{1}$, Muhamad Fathul Muin ${ }^{2}$ \\ ${ }^{1}$ BPS-Statistics Boalemo, Indonesia \\ ${ }^{2}$ BPS-Statistics Papua, Indonesia
}

Corresponding Author: Muhamad Fathul Muin; Email: fathul.muin@bps.go.id

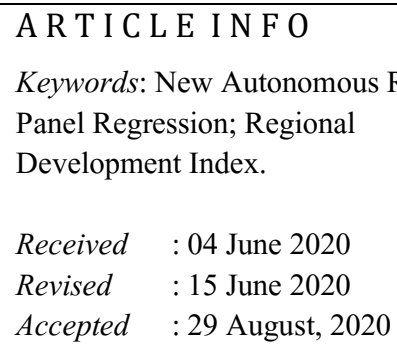
\begin{abstract}
A B S T R A C T
This research is motivated by the high interest of the people and the People's Representative Council (PRC) to make their regional autonomous. On the other hand, according to the Ministry of the Interior of the New Autonomous Region, the results of the autonomous region still failed to develop. To see the welfare of the people in the region resulting from the autonomous, researchers tried to look at it based on the results of regional macro development. Therefore, a Regional Development Index (RDI) constructed, which uses the factor analysis weighting method. RDI can be used to see the achievements of the regional development in Indonesia by looking at the comparison of development outcomes. So that RDI can see the development performance of the new autonomous regency/city and see the comparison with the origin regency/city. Besides, researchers looked at the effect of the share of mining Regional-GDP, the share of agricultural Regional-GDP, the average length of school for workers (ALSW), the percentage of roads in a minimum good condition and the growth of regional original income (ROI) to development performance in the autonomous regency/city using the method of regression analysis with panel data. Based on the results obtained, development in the area of new autonomy is not much different from the development in the origin area. Also, the average length of school for workers (ALSW) and minimum road percentage both have positive and significant effects on RDI, while the share of agricultural GRDP has a negative and significant effect on RDI.
\end{abstract}

\section{INTRODUCTION}

One of the national goals of Indonesia's development is the creation of general welfare for all its citizens (Suhartono, 2002). The effort to achieve this goal, the government must be able to create stable and sustainable development. Various ways have been carried out by the government to realize it. One of them is the regional autonomous policy. According to the National Planning Agency (2014), the main reason for the region want to be autonomous is trying to create independence and accelerate regional development. Other than it, autonomy is a means of political education for the local level government in order to improve community welfare.

Conceptually, regional autonomy is the right, authority, and obligation of autonomous regions to regulate and manage their government affairs and the interests of local communities in the Unitary State of the Republic of Indonesia system (Djohan, 1990). The enactment of regional autonomy will give local governments the authority to plan and implement policies and programs following their respective regional potentials. Therefore, regional development expected to be even better. Tenrini (2013) states the reasons for the division of regions, namely: (i) the unequal distribution of justice, (ii) broad geographical conditions and ineffective and inefficient community services, (iii) differences in civil society developing in society, (iv) the lure of fiscal incentives, and (v) supremacy status.

Based on data from the Directorate General of Regional Autonomy (Dirjen Otda), in 2014, there were 542 autonomous regions in Indonesia with 223 autonomous regions resulting from the new blossomed (Gunawan, 2018). The number shows 
that amount of autonomous regions is enormous. Almost half of the existing autonomous regions previously resulted from the blossomed regions. The establishment of new autonomous regions will have significant implications for the State Budget in the provision of transfer funds to regions and funding sourced from vertical agencies (Kemenkeu, 2015). Therefore, the blossom of regions will cause pressure on the State Budget due to the number of funds that must be transferred to the new local government. Especially if a region has not been able to optimize its regional potential, the region will have a negative effect on the State Budget.

Regional autonomy carried out to optimize coverage service to the community (Rasyid, 2007) and expected to increase income distribution and reduce poverty. However, the proliferation of regional autonomy that exists today cannot overcome inequality between regions in Indonesia. It is consistent with the findings of Aloysius G. Brata (2009), which states that blossoming can cause imbalances between regions that have become more severe. Another problem is that based on a study from the Ministry of Home Affairs, it found that 65 per cent of existing autonomous regions failed to develop (Dirjen Otda, 2011).

All of the previous descriptions show that the regional autonomy that occurred in Indonesia still causes pros and cons in the community. It is allegedly because the newly created autonomous regions have not been able to carry out development activities independently and are still dependent on equalization funds from the central government. Therefore, clear standards needed for a region to see the results of development and know the variables that drive the progress of the area. So, it will help the government in achieving stable and sustainable development to create prosperity for its people. Therefore, this research expected to obtain: Description of the development achievement of regency/city resulting from the blossoming in Indonesia during the period 2010-2014; The achievement of the development of regency/city resulting from the blossomed in Indonesia compared to the origin region during the period 2010-2014; The variables that affect the development result of the blossomed region in Indonesia during the 2010 to 2014 period.

\section{Materials AND Methods \\ The Scope of Research}

This research covers 86 regencies/cities in Indonesia with 49 regions resulted from the blossom, and the remaining 37 are origin regencies/cities. The selected regencies/cities are limited to the regencies that divided in 2003. It caused by the many numbers of autonomous regions that year. So, these regencies/cities in this research spread throughout Indonesia except JavaBali. This research carried out from 2010 to 2014 . The initial year of 2010 has chosen caused by quite stable conditions after turmoil in 2008. Besides, many new methods perfected in 2010 , such as the calculation of HDI, RGDP, etcetera.

\section{Method of collecting data}

The data used in this study obtained from BPSStatistics Indonesia, including:

1. Human development index (HDI)

2. Gini coefficient

3. GRDP growth

4. GRDP per capita at the 2010 constant price (CP RGDP)

5. Percentage of the poor population

6. Open unemployment rates

7. Mining RGDP contribution

8. Contribution of agriculture RGDP

9. Percentage of roads of minimal good condition

10. The average length of schooling of workers

11. Growth in Local Own Revenue (ROI)

\section{Critical Framework}

The success of the development in a region will affect the level of social welfare. If there is an inequity between regions, the government needs to take action to overcome it appropriately. Therefore, this research begins with the identification of problems, determining the objectives, and collect related literature studies. All of it aims to obtain the right variables to describe the phenomena. The next step is carried out with relevant data collection. After that, the variables processed and analyzed, then the results used to draw conclusions and suggestions. As a general view, the following is a research framework: 


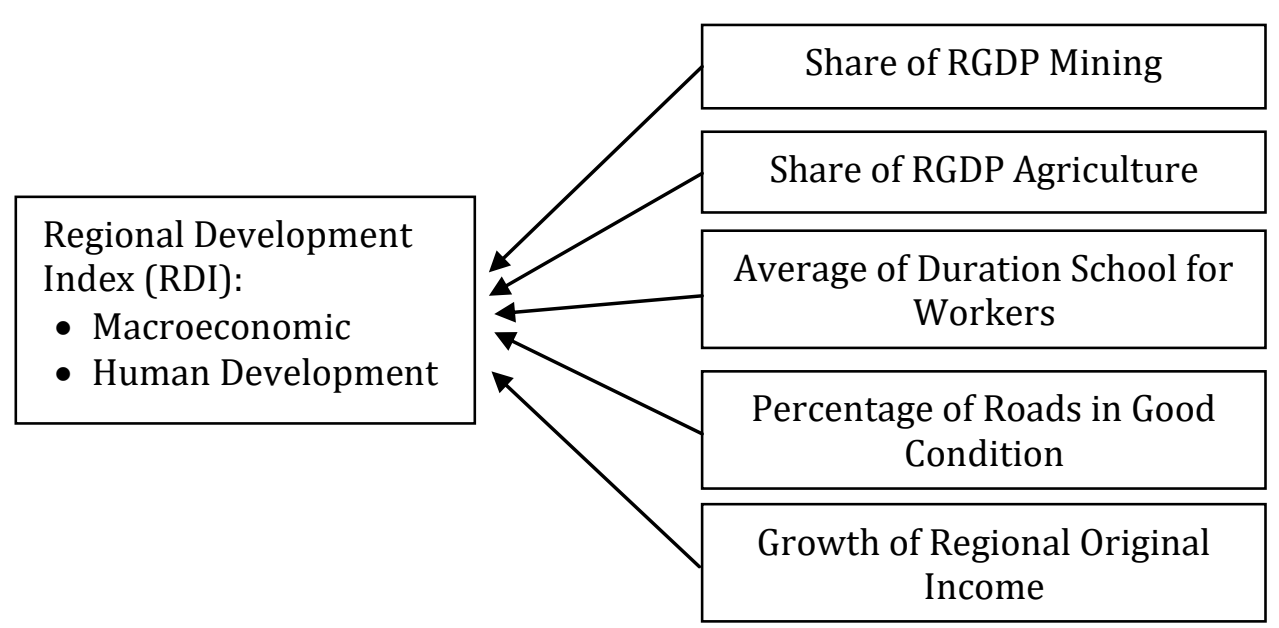

Figure 1. The Critical Framework

\section{Analysis Method: Composite Index}

The composite index was chosen to facilitate the process of identifying the development achievements of the city district. It is done because the use of a composite index will make it easier for the public to understand the existing conditions compared to seeing trends from several indicators together. Some variables that researchers use in compiling the development index as like in table 1.

Table 1. The Variables Used in Preparing the Regional Development Index (RDI)

\begin{tabular}{ll}
\hline \multicolumn{1}{c}{ National Development Macro Targets } \\
\hline Human Development & \multicolumn{1}{c}{ Macroeconomic } \\
Human development index & Economic growth \\
Gini index & RGDP per capita basic year of 2010 \\
& Poverty rate \\
& Open unemployment rate \\
\hline
\end{tabular}

The index preparation method used in this study adopted the method used by the $\operatorname{OECD}(2008)$. The following are some of the steps for indexing:

1. Preparation of a theoretical framework

2. Selection of indicators must be based on reliability, scalability, data availability, spatial coverage, relevant and inter-connected

3. Imputation of lost data

4. Multivariate analysis

5. Normalization

6. Weighting and aggregation

7. Resilience and sensitivity

8. Return to original data
9. Relation to other variables

10. Presentation and dissemination of results

\section{Inference Analysis}

The inference analysis used in this study is factor analysis and multiple linear regression analysis with panel data. The factor analysis used as a method in finding weighting values in the preparation of composite indexes. The analysis with panel data con-ducted to determine the factors that influence the achievement of new autonomous regions performance. For the method executed using Eviews. Typical forms of research models with panel data are:

$$
\begin{array}{ll}
\mathrm{RDI}_{\text {it }}=\left(\alpha+\mathrm{u}_{\mathrm{i}}\right)+ & \beta_{1} \text { Mining }_{\text {it }}+\beta_{2} \mathrm{Agri}_{\text {it }}+\beta_{3} \mathrm{ALSW}_{\text {it }}+\beta_{4} \mathrm{Road}_{\text {it }}+\beta_{5} \mathrm{LN}_{-} \mathrm{ROI} \\
\text { Which, } & +\mathrm{v}_{\text {it }} \\
\text { RDI } & : \text { Regional development index } \\
\text { Mining } & : \text { Contribution of the mining sector RGDP to total } \\
\text { Agri } & : \text { Contribution of agriculture sector GDP to total } \\
\text { ALSW } & : \text { Average length of school workers (ALSW) } \\
\text { Road } & : \text { Percentage of roads with minimal good conditions } \\
\text { LN_ROI } & : \text { Growth of regional original income (ROI) }
\end{array}
$$


i $\quad$ : Regency/city resulted from blossomed (Bener Meriah, ..., Supiori)

t : Research period (2010, 2011, 2012, 2013,2014)

\section{RESULTS AND DISCUSSION}

\section{The Results of Regional Development Index}

The regional development index (RDI) shows the development achievements of the regency/city in Indonesia by looking at the comparison of the development outcomes of the regency/city in a particular year. Besides, RDI can also be used to see the development progress in a particular district.

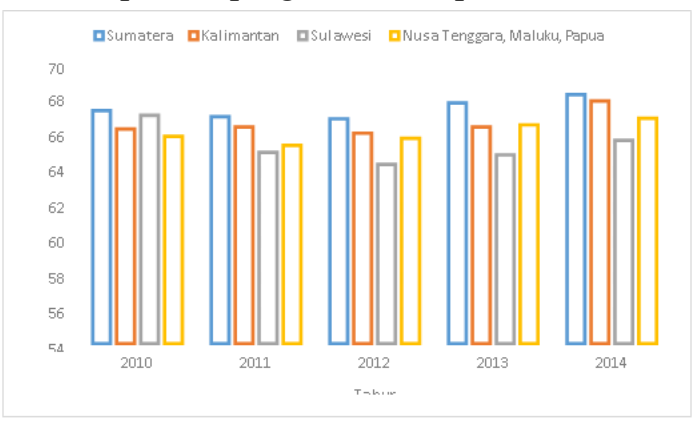

(2a.) Human Development
RDI can be composed into two dimensions, namely human development and macroeconomic development. The human development score illustrates the quality of human capital and the disparity in expenditure between residents in a region whereas the macroeconomic score illustrates the achievement of macro-economic and employment in a region.

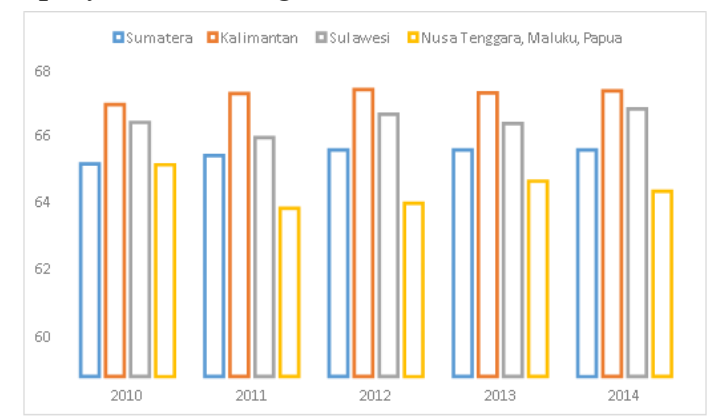

(2b.) Macroeconomic

Figure 2. The Human Development Scores and Macroeconomic Scores

Generally, from the results of RDI score decomposition in Figure 2, there is differences in characteristics between one region and another. From the human development aspect, since 2011, the score for the regency/ city in Sulawesi has always occupied the last position. It is due to the high Gini ratio between the region causes the score of human development tend to below. Even so, when viewed from the macroeconomic score of the blossomed regency/city in Sulawesi, the average score was quite high above the regency/city in

Table 2. Regional Development Index (RDI)
Sumatra and Nusa Tenggara, Maluku, Papua. It can indicate that even though the achievement value in the economic field is quite high, there is an imbalance in the urban regions in Sulawesi. In contrast to human development scores, the macroeconomic scores of urban regions in Nusa Tenggara, Maluku, and Papua have a much lower value than other regions. It is in line with the condition in this region in which the unemployment rate tends to rise, and the percentage of poverty is high.

\begin{tabular}{lccccc}
\hline \multicolumn{1}{c}{ Region } & 2010 & 2011 & 2012 & 2013 & 2014 \\
\hline Kab Balangan & 67,94 & 69,41 & 68,34 & 70,08 & 71,45 \\
Kab Bangka Barat & 68,09 & 67,25 & 68,79 & 69,55 & 69,04 \\
Kab Belitung Timur & 67,66 & 68,38 & 67,98 & 69,34 & 69,20 \\
Kab Mamuju Utara & 69,88 & 68,72 & 68,60 & 65,57 & 69,12 \\
Kota Tidore & 68,04 & 66,78 & 67,70 & 67,49 & 68,66 \\
& $\vdots$ & $\vdots$ & $\vdots$ & $\vdots$ & $\vdots$ \\
Kab Manggarai Barat & 61,09 & 59,97 & 61,22 & 60,94 & 62,40 \\
Kab Seram Bagian Barat & 60,44 & 59,84 & 61,36 & 61,43 & 61,89 \\
Kab Kepulauan Aru & 60,70 & 59,90 & 60,64 & 60,69 & 61,91 \\
Kab Seram Bagian Timur & 60,93 & 59,41 & 60,89 & 59,93 & 62,31 \\
Kab Supiori & 57,48 & 61,62 & 60,68 & 59,86 & 61,47
\end{tabular}

Meanwhile, Table 2 illustrates the five regions which have the highest and lowest index from 2010 to 2014. Based on the table, it can be seen that five regions with the highest index spread evenly across regions, namely Sumatra, Kalimantan and Sulawesi. As for the five regions that have the lowest indexes, they are all regency in the Nusa Tenggara, Maluku and Papua regions. This condition must be of 
concern, exceeded for regional government with low RDI scores.

\section{Achievement of Regencies/Cities Resulting from the Blossomed and Comparison with Origin Regions}

From 2010 to 2014, the development index values from blossomed and origin regions tend to be constant with a slight increase at the end of the study period. From the figure 3 , it seems at first the index of the blossomed region even higher compared to the origin region. Whereas in 2011 and
2013, the origin regions could outperform than blossomed region. Until finally in 2014 the opposite condition occurs again. Viewed from the origin regions, the current RDI values in 2011 and 2012 always decreased with only started to rise again in 2013. Unlike the case with the blossomed regions, which since 2011 experienced a slight decline, in the following years the RDI values tend to ride. This condition shows that maybe the blossomed regions are mature enough or have started to optimize the potential of their respective regions.

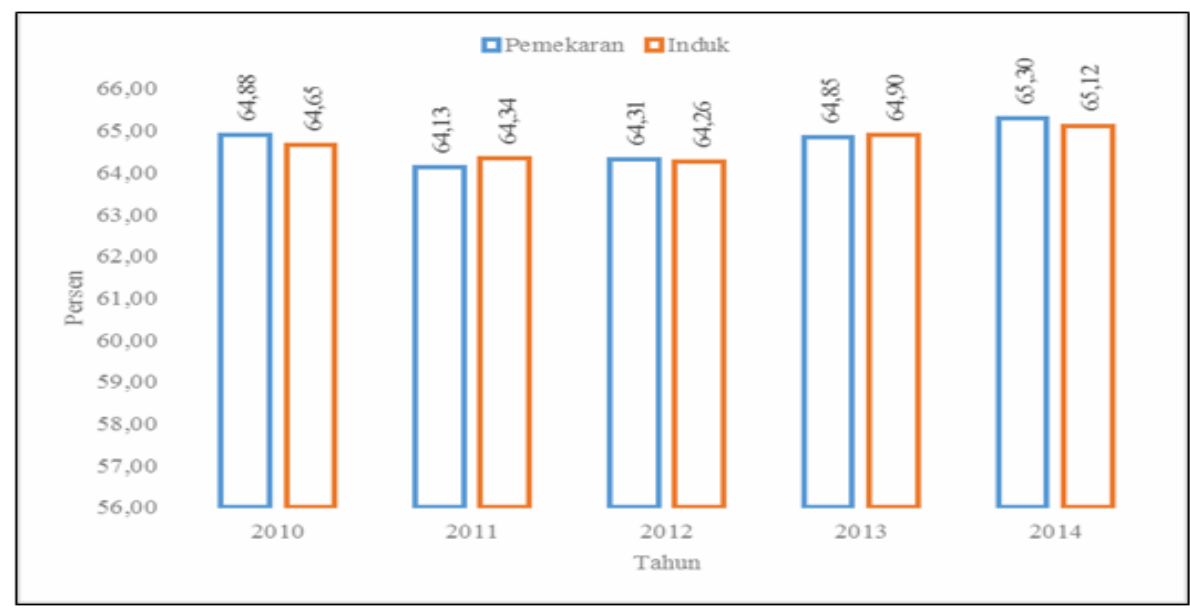

Figure 3. Comparison of RDI between Blossomed and Origin Regions in Indonesia 2010-2014

If looked carefully, there is a new problem, during the five years there has not been a significant increase in development both the area of blossomed and origin regions. Even though the blossomed region can compensate for the development of the origin region, the development of the blossomed region still far from the target. The conditions which the development does not show a significant increase over the past five years will initiate the people disappointed in economic performance, especially for government performance. This problem needs to be a concern both central and regional governments and needs to handle it wisely.

Apart from the still low development achievements, figure 3 also illustrates that the blossomed region has a lower RDI value than its origin region, but the increase in the value of RDI that occurred in the blossomed region was faster so that in 2014 the RDI value of the blossomed region was higher. This condition shows that not all areas resulting from the blossomed are behind their origin regions. It is the reasons why an area separates from the origin region caused by consideration of the potential resources in their area, while for the origin region with left behind, caused by the potential sources of the regions they have been diminishing.

\section{Variables that Affect the Achievement of Performance}

In the previous description, it can be seen that there are still differences and variations in the value of RDIs between blossomed and origin regency/city. In order to obtain a region with a high $\mathrm{RDI}$, the government needs to know the variables that affected. It is intended that as a consideration to determine a policy or decide on a region is appropriate to be divided or not. The variables such as the contribution of the RGDP in the mining sector, the RGDP in the agriculture sector, ALSW, the percentage of roads in a minimum good condition, and the growth of ROI were chosen to be seen for their effects on RDI. These variables are chosen based on the concept of the production function. The production function which states that there is a relationship between factors of production (input) with the level of output produced. However, this time the production factors that are seen are quality, such as ALSW, which describe the quality of workers in the region, the percentage of good 
road conditions that try to represent the quality of infrastructure in the area, etcetera. Meanwhile, RDI is seen as the output of production.

\section{Model Selection}

The selection of the best model is done by estimating three possible models in panel data analysis, namely the common-effect model, the fixed-effect model, and the random-effect model.
First, using the F-test to find a better estimation model between the common-effect model and the fixed-effect model. The test results show to reject the null hypothesis because of the p-value smaller than 0.05 . It means that there are differences in individual effects, so the fixed-effect model is better than the common-effect model.

Table 3. The Result of Chow Test

\begin{tabular}{lrrr}
\hline Effects Test & \multicolumn{1}{c}{ Statistic } & d.f. & \multicolumn{1}{c}{ Prob. } \\
\hline Cross-section F & 9,366009 & $(48,191)$ & 0,0000 \\
Cross-section Chi-square & 296,470219 & 48 & 0,0000
\end{tabular}

Then the Hausman test is performed to see whether the fixed-effect model is better than the random-effect model. The test results obtained to reject the null hypothesis, meaning that there is a correlation between the regressor and individual effects. In other words, the fixed-effect model is better than the random-effect model. Based on the two tests carried out, it can conclude that the right model used is the fixed-effect model, then the Pagan Breusch testis not necessary.

Table 4. The Result of Hausman Test

\begin{tabular}{lccc}
\hline Test Summary & Chi-Sq. Statistic & Chi-Sq. d.f. & Prob. \\
\hline Cross-section random & 20,4446 & 5 & 0,0010 \\
\hline
\end{tabular}

After finding the fixed-effect model as the best estimation, the next step is to identify the residual of variance-covariance structure. It is intended to avoid a fixed-effect model biased. The test statistic used is the LM (Lagrange Multiplier) test. The test results show that the LM test value of 160.596 . This value is greater than the critical value of 65.171 , so the conclusion must to reject the null hypothesis. This result means that the variance-covariance structure is heteroscedastic.

After finding out that the residual variancecovariance matrix structure is heteroscedastic, then the next testing is to determine whether there is a cross-sectional correlation or not by using the Lambda LM test. The Lambda LM result is 1728.316 and greater than the value $\chi_{0.05 ; 10}^{2}$ which is 1256.892. So, it can be concluded that the variancecovariance structure is heteroscedastic, and there is a cross-sectional correlation. Because the number of individuals (regency/city) is greater than the time series data (research period), the SUR weigher cannot be used. To overcome this problem, an estimator that is robust to autocorrelation is needed. Finally, the fixed-effect model is estimated using the FGLS method with SUR Panel Corrected Standard Error/PCSE (Verbeek, 2014).

\section{Assumption Testing} Normality

The Jarque-Bera statistical test results as like in figure 4 , show that the test probability value is more than a critical value of 0.05 , so it can be concluded that the null hypothesis failed. This result means that at the test level of five per cent of the selected estimation residual model is normally distributed. 


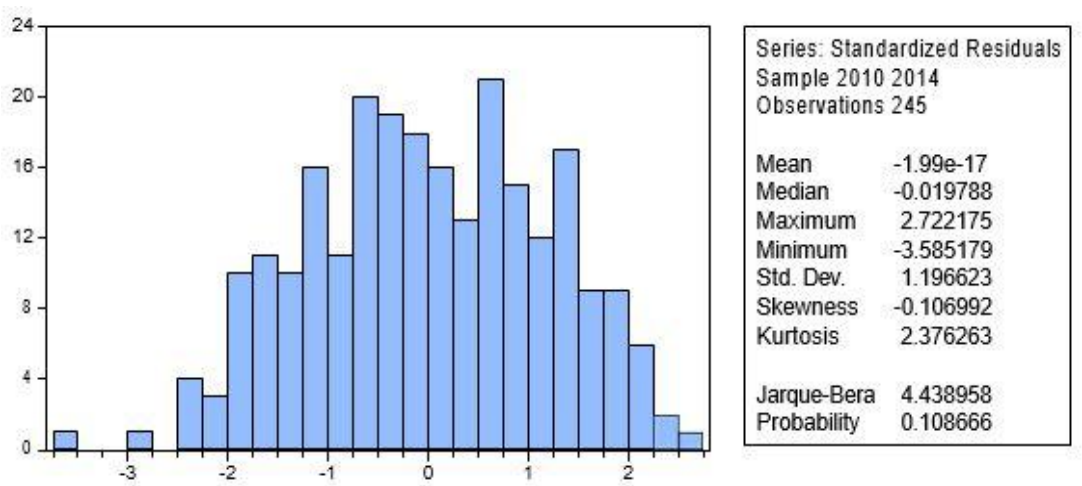

Figure 4. The Result of Normality Test

\section{Nonmulticolinearity}

The results using correlation tests as like in table 5, show that there is no multicollinearity between data. It showed us the correlation value between variables is less than 0.8 , so it can be concluded that the assumption of nonmulticollinearity is fulfilled.

Table 5. The Result of Crosssection Test

\begin{tabular}{lcrrrr}
\hline & TAMBANG & TANI & JALAN & \multicolumn{1}{c}{ MYS } & LNPAD \\
\hline TAMBANG & 1,0000 & $-0,7128$ & 0,0270 & $-0,1002$ & 0,4232 \\
TANI & $-0,7128$ & 1,0000 & $-0,0503$ & 0,0382 & $-0,3847$ \\
JALAN & 0,0270 & $-0,0503$ & 1,0000 & 0,1661 & $-0,0450$ \\
MYS & $-0,1002$ & 0,0382 & 0,1661 & 1,0000 & $-0,0951$ \\
LNPAD & 0,4232 & $-0,3847$ & $-0,0450$ & $-0,0951$ & 1,0000 \\
\hline
\end{tabular}

\section{The Selected Model and the Meaning}

After going through several stages of testing, the best estimation model chosen is the fixed-effect
(FEM) model with a cross-section weighing SUR (PCSE). Following are the estimation results from the FEM model with SUR weighers (PCSE):

Table 6. The Final Model Estimation (FEM PCSE)

\begin{tabular}{lrrrr}
\hline \multicolumn{1}{c}{ Variable } & Coefficient & Std. Error & t-Statistic & \multicolumn{1}{l}{ Prob. } \\
\hline C & 64,32579 & 5,15881 & 12,46911 & 0,0000 \\
TAMBANG & 8,95134 & 8,29808 & 1,07872 & 0,2821 \\
TANI & $-10,19597$ & 3,84130 & $-2,65430$ & 0,0086 \\
MYS & 0,13821 & 0,06528 & 2,11703 & 0,0356 \\
JALAN & 0,00658 & 0,00190 & 3,46419 & 0,0007 \\
LNPAD & 0,08722 & 0,17295 & 0,50430 & 0,6146 \\
\hline R-squared & 0,91721 & F-statistic & 39,92559 \\
Adjusted R-squared & 0,89424 & Prob(F-statistic) & 0,00000 \\
\hline
\end{tabular}

From the results obtained in table 6 , the equation can be arranged as follows:

$$
\begin{aligned}
\mathrm{RDI}_{\mathrm{it}}= & \left(64.3258+\mathrm{u}_{\mathrm{i}}\right)+8.9513 \text { Mining }_{\mathrm{it}}-10.1960 \\
& \text { Agri }^{{ }^{*}+}+0.1382 \mathrm{ALSW}_{\mathrm{it}}{ }^{*}+0.0066 \mathrm{Road}_{\mathrm{it}}{ }^{*}+ \\
& 0.0872 \mathrm{LN}_{-} \mathrm{ROI}_{\mathrm{it}}
\end{aligned}
$$

Note: * significant at $\alpha=5 \%$

The results of the overall testing using the Ftest obtained a p-value smaller than 0.05 so that at a significance level of five per cent, it can be concluded rejecting the null hypothesis. This result means that at a five per cent significance level, there is at least one independent variable that has a significant effect on the RDI of the blossomed region. This result strengthened by the adjusted Rsquared value of the model generated by 0.8942 per cent. It means that the diversity of independent variables can explain 89.42 per cent of the diversity of RDI. Meanwhile, the remaining 10.58 per cent is explained by other variables not included in the 
model. As partially, from table 6 , it shows that from the five independent variables, three independent variables significantly influence the RDI variable. These three variables are the contribution of the agricultural sector to the RGDP, the average length of worker's school (ALSW), and the percentage of roads in a minimum good condition.

The results of calculations using the fixedeffect model show that there are differences in each intercept as many observational variables. This model showed the existence of individual effects that differentiate each unit of observation. In this study, the number of the blossomed region was 49 regions (divided in 2003), so there were also many intercepts. Based on the individual effects of region, North Mamuju, Serdang Bedagai and Humbang Hasandutan are the three regencies with the highest intercepts. It shows that they have RDI above average and tend to increase every year (ceteris paribus). Meanwhile, West Sumbawa, East Seram and East Luwu are the three regions with the lowest intercept. Even though these three districts are not the three districts with the lowest RDI scores, their fluctuating and declining values make these three districts have the lowest intercept values.

The regression results show that the share of mining RGDP has a positive but not significant effect on RDI. The regression coefficient value is 8.9513, which means that each increase of one per cent of the mining RGDP share will cause the RDI value to increase by 8.9513 per cent (ceteris paribus). Although this variable is not significant, it does not mean that this variable does not affect. Suciyanti et al. (2018) state that the mining sector has an important role both in RGDP and total output. The insignificant results might be because many regions have high RDI values, although the contribution of the mining sector is not too enormous.

Furthermore, the regression results show that the share of RGDP in the agricultural sector has a negative and significant effect on changes in RDI values. The regression coefficient of -10.1960 means that each increase of one per cent of the share of agricultural RGDP will cause the RDI value to decrease by 10.1960 per cent when other independent variables are in a constant condition. This negative coefficient value is not directly interpreted if an area wants to have a high RDI value must reduce the contribution of the agricultural sector. This negative value illustrates that most of the newly established regions that still depend on the agricultural sector are less able to develop. Also, this value indicates that the agricultural sector generally is still lacking attention. It causes the added value generated from this sector is still small, so it has not been able to improve the welfare of the community in general.

Regression results show that the average length of schooling for workers (ALSW) has a positive and significant effect on changes in RDI scores. The regression coefficient value is 0.1382 , which means that every one year increase in the average length of schooling or education of workers will increase the RDI by 0.1382 per cent. The ALSW value of these workers can reflect the level of education or quality of workers in a region. The importance of education in development have seen when education become one of the HDI dimensions. The challenge in the labour market regarding the ability and education of the workforce need special attention. If the region has the potential for a qualified economy like a mine, but the people are not qualified will backfire for this region. Workers will easily take existing employment opportunities from other regions, even by foreign workers. Also, the creation of an educated workforce will be freer in determining their careers.

Regression results show that the percentage of roads with minimal conditions both has a positive and significant effect on changes in RDI. The regression coefficient value 0.0066 means that every one per cent increase inroads with minimal good conditions can increase the RDI value by 0.0066 per cent. Roads are one of the essential infrastructures in supporting the achievement of regional development. The prices are related to the technical attributes of the transport services (Combes et al., 2015). So, with a good road conditions, economic activities will run more smoothly. This condition occurs because when the more difficult to access an area, the higher the price level in the area. When the price level gets higher, the purchasing power of the people will decrease, this will undoubtedly affect the economic conditions of the area. Unlike the case, if there is easy and cheap access, with lower transportation costs because of easy access, the level of prices of goods will decrease. With the declining price level, the purchasing power and economic enthusiasm of 
the community will increase so that the wheels of the economy will run more smoothly.

The last results are that there is a positive influence on the growth of regional original income (ROI), although not significantly. The regression coefficient value of 0.0872 means that each ROI growth of one per cent will increase the RDI value of 0.0872 per cent. Insignificant results might be caused by the impact of ROI on the indirect economy. ROI is one of the regional revenues that can later be used in the development or capital expenditure. Investments made such as by building bridges, infrastructure, etcetera are efforts to facilitate economic activities, the process is not short-lived, and the feedback is indirect, so the impact of ROI cannot be enjoyed directly.

Even so, ROI is one of the regional revenues that must be optimized so that the region can provide better services and facilities for the community. Of course, excellent services and facilities require more funds from local governments. With the enactment of regional autonomy, local governments have flexibility in managing their regional finances. Even so, the local government should not impose a source of income on increasing taxes that would slow down the economy. One way that can be taken is the efficiency of regional owned enterprises (ROE) to increase its contribution to regional income.

\section{CONCLUSION}

Generally, there is no difference too far between the development of the blossomed region and its origin. However, at the beginning and the end of the study period, the results were obtained that the RDI value of the blossomed region was higher than the origin. In line with that, in 2014 around 69 per cent of the newly autonomous regions had not been able to pass the RPJMN baseline; even for origin regions around 73 per cent had not been able to pass the baseline. This finding is opposite to the opinions that arise in the community, which considers the origin region more advanced than the blossomed region.

Based on panel regression analysis using the fixed-effect model with a SUR weighted (PCSE), the results obtained that the share of agricultural RGDP, Average length of school workers (ALSW) and the minimum percentage of good road conditions significantly influence changes in RDI values. Meanwhile, the share of mining RGDP and the growth of regional original income (ROI) have a positive but not significant effect on RDI values.

\section{REFERENCES}

Aloysius G., B. (2009). Will Creating New Regions Improve the Regional Welfare Equality? Buletin Ekonomi Moneter, 275-286.

Bappenas. (2014). Rencana Pembangunan Jangka Menengah Nasional (RPJMN) 2015-2019 Buku 1. Badan Perencanaan Pembangunan Nasional.

Combes, F., Harache, J., Koning, M., \& Morau, E. (2015). Empirical Analysis of Freight Transport Prices Using the French Shipper Survey ECHO. 1-15.

Dirjen Otda. (2011). Laporan Hasil Evaluasi Daerah Otonom Hasil Pemekaran (EDOHP). Kementrian Dalam Negeri.

Djohan, D. (1990). Problematik Pemerintahan dan Politik Lokal. Bumi Aksara.

Gunawan, H. (2018). Mantan Dirjen Otda: 80 Persen Pemekaran Daerah Gagal [News]. Tribunnews.com.

https://www.tribunnews.com/nasional/2018/0

9/07/mantan-dirjen-otda-80-persenpemekaran-daerah-gagal

Kemenkeu. (2015). Nota Keuangan dan Anggaran Pendapatan dan Belanja Negara Tahun Anggaran 2015. Kementerian Keuangan.

OECD. (2008). Handbook on Constructing Composite Indicators Methodology and User Guide. OECD Publishing.

Rasyid, R. (2007). Otonomi Daerah dalam Negara Kesatuan. Pustaka Pelajar.

Suciyanti, M., Suseno, T., \& Saleh, R. (2018). Analisis Dampak Kegiatan Pertambangan Tembaga terhadap Perekonomian Provinsi Papua. Jurnal Teknologi Mineral Dan Batubara, 75-92.

Suhartono, E. (2002). Cooping Strategies dan Keberfungsian Sosial: Mengembangkan Pendekatan Pekerjaan Sosial dalam Mengkaji dan Menangani Kemiskinan. Kemiskinan dan Keberfungsian Sosial: Merancang-Kembangkan Program Pembangunan Kesejahteraan Sosial yang Bernuansa Pekerjaan Sosial. 
Tenrini, R. H. (2013). Pemekaran Daerah: Kebutuhan atau Euforia Demokrasi? Mengapa Harus Mekar. Kementerian Keuangan.

Verbeek, M. (2014). A Guide to Modern Econometrics (2nd ed.). John Wiley \& Son, Ltd. 